\title{
1. Globalisation as crisis
}

\section{REFLECTIONS}

Twenty years back, I had written that globalisation represented the collapsing of time and space through new technologies of communication. ${ }^{1}$ While I suspected globalisation as a move to monoculture, in reality the trappings are more a superficial manifestation of modernisation and materialism. If globalisation is a process and not a thing, then it can carry any message the hegemony requires, provided in so doing it does not defeat its integrating potentials. Since then, my view has shifted to seeing globalisation defined in terms of risk and security. ${ }^{2}$ Associated with such a 9/11 myopia was an upsurge of interest in global governance both formal and informal. ${ }^{3}$ Then came the flu pandemics, and globalisation was sociability in panic to save your health, and that of your families. $^{4}$

Undeniably, with the imperialist exportation of 'free trade' and the relationships of obligation and dependency between the South-to-North worlds, globalisation developed into a mechanism for proliferating a neo-colonial, neoliberal economic order. ${ }^{5}$ However, as the disempowering realities of exclusionist commodification essential to the neoliberal project bit deeper, the propaganda that this global economic order was good for all soon evidently failed the tests of social justice and cultural integrity. As a result, globalisation was seen by many radical and disenfranchised protest movements to be the cause

1 M. Findlay (1999) The Globalisation of Crime: Understanding Transitional Relationships in Context, Cambridge: Cambridge University Press.

2 M. Findlay (2013d) 'Regulation and Governance - Beyond Terror/Risk/ Security', in M. Findlay Contemporary Challenges in Regulating Global Crises, Basingstoke: Palgrave Macmillan, pp. 248-70.

3 M. Findlay (2013c) 'International Criminal Justice and Global Governance: Governing through Risk, Security and Justice', in M. Findlay International and Comparative Criminal Justice: A Critical Introduction, Abingdon: Routledge, pp. 172-96.

4 M. Findlay (2013) Contemporary Challenges in Regulating Global Crises, Basingstoke: Palgrave Macmillan, chap. 6.

5 M. Findlay (2017) Law's Regulatory Relevance: Property, Power and Market Economies, Cheltenham, UK and Northampton, Mass., USA: Edward Elgar, chap. 5. 
of savage exploitation, rather than an opportunity to arrest the true source of social and economic marginalisation. ${ }^{6}$ In this climate of aversion, authoritarian populist politics has demonised even the inclusive and remediating potentials of globalisation, while at the same time pretending their possibility within populism. $^{7}$

I write this present reflection on globalisation at the opening of a new decade when the fundamentals of liberal democracy are serially disrespected; the world trade reality is protectionism and national self-interest above hegemonic imperialism; vast populations are being displaced and on the move; millennials are rioting in the streets from Hong Kong to Sao Paulo protesting their squandered futures; and Australia is ablaze. Sydney, where I am located, is blanketed in acrid smoke and ringed with fire. Half the wildlife populations in the major national parks have been incinerated, raising the list of species extinction to catastrophic levels. The human cost has still not been sufficient for the climate change deniers to experience the scales falling from their eyes or the blatant untruths silenced from their mouths. Politics is failing reason. The ship of fools is leaking and adrift. Populations are losing hope. Even anger is being replaced by a febrile sense of inevitability. Whether it is rising sea levels, massive floods, shocking droughts, volcanoes reborn, cyclonic cataclysms, quakes and infernos, mother-nature has had enough of human intractability.

Now I see globalisation above all else as the shared consequences of climate crisis. Of course, this will have economic, political, cultural and social dimensions, but there is no escaping that moving past the tipping point of 2020, globalisation is the platform for both communitarian response and revisionist destruction. Global warming, like no other contemporary crisis, scoffs at jurisdictions, races, cultures and separatist histories. Never before have we all as global citizens shared a common fate such as we do at this moment.

In an article entitled 'Australia Shows Us the Road to Hell', critical economist Paul Krugman observes:

if a nation in flames is not enough to produce a consensus for action [on climate change] - if it isn't even enough to produce some moderation in the anti-environmentalist position - what will? ${ }^{8}$

6 B. De Sousa Santos and C. Rodriguez-Garavito (eds) (2005) Law and Globalization from Below: Towards a Cosmopolitan Legality, New York: Cambridge University Press.

7 R. Zoellick (2007) 'Towards an Inclusive and Sustainable Globalization', The World Bank https://www.worldbank.org/en/news/speech/2007/10/10/an-inclusive -sustainable-globalization (accessed 3 June 2020).

8 P. Krugman (2020) 'Australia Shows Us the Road to Hell', New York Times https://www.nytimes.com/2020/01/09/opinion/australia-fires.html (accessed 3 June 2020). 
Rejecting the diminishing impact of scientific truths, and recognising the dangerous self-interest of scientifically literate conservative climate deniers, Krugman asks 'what hope is there for avoiding the apocalypse?' Being a political economist, he returns to the need to connect climate action with immediate electoral benefit through a Green New Deal - massive infrastructure spending on a 'large climate industrial complex' creating jobs and political goodwill. This leaves me cold. It is a policy bereft of considering South world participation beyond what slows down North world emissions is good for the globe. Additionally, it gives up on pressing home personal responsibility as global citizens, and ignores the one feature of globalisation outside its economic manifestations that has offered comfort in so many crises past - solidarity.

In my work on regulating contemporary crises, ${ }^{9} \mathrm{I}$ employed the analytical technique of sociability to bring solutions back down to the communal. At its simplest, sociability is a process of identifying shared risk and mobilising to shared fate. Despite the most evil efforts of the climate-denying elite (who are also the master manipulators of anxiety governance), the recognition of shared risk has taken to the streets. As for what will lead communities to link up in shared fate will not be the shattered social bonds of trust, ${ }^{10}$ savagely eroded through neoliberal individualist rapaciousness. No - what is much more likely as the motivating force is a mutualising of the most basic survival instincts which you see in the epidemic responses to health pandemics. ${ }^{11}$ Globalisation is the information pathway to both the mutualisation of interests and rapid response. The basic question for global sustainability is whether this comes all too late. The answer to the global catastrophe which is fast characterising the toxic economic and social consequences on neoliberal economic models that see climate as an exchange commodity, is not through resisting globalisation, but rather resisting the globalisation of that economic model which is the way to inevitable destruction.

In their comprehensive overview of the forms and forces of recent resistance to globalisation, Kellner and $\mathrm{Kahn}^{12}$ see the diverse oppositional movements as trying to constitute the beginnings of a global civil society that might produce new public spheres of political debate and cosmopolitan culture, and in different measure upholding values of autonomy, democracy, peace, sustainability,

9 D. Inglis (2011) 'A Durkheimian Account of Globalization: The Construction of Global Moral Culture', Durkheimian Studies 17, 103-20.

10 Findlay (2013).

11 Findlay (2013).

12 D. Kellner and R. Kahn (2007) 'Resisting Globalisation', in G. Ritzer (ed.) The Blackwell Companion to Globalization, Oxford: Blackwell; pp. 662-74 https:// pages.gseis.ucla.edu/faculty/kellner/essays/resistingglobalization.pdf (accessed 3 June 2020). 
equality and social justice. Anti-corporate globalisation has opposed technopolitics and its exclusionist sub-cultures. In their view, the attempts to relocate a 'globalisation-from-below' are in direct response to today's mainstream ruling practices, neoliberal capitalist economics, repressive cultural norms and other aspects of global society that appear to augment the divides between rich and poor and oppressor and oppressed. ${ }^{13}$

\section{GLOBALISATION AS RESISTANCE TO NEOLIBERAL ESSENTIALISM? THE TROJAN HORSE OF CONSTITUTIONALISM}

Until recently, the process of globalisation has been captured by the neoliberal economic model. ${ }^{14}$ Consequentially, not only is state-centred constitutional legality challenged by neoliberal small statism, ${ }^{15}$ but mega-corporate capitalism has shifted the market/social focus from nation states to multi-national alliances. ${ }^{16}$ Arguably, jurisdictionally embedded notions of constitutional legality are becoming less relevant as the core of international governance, certainly being the case in transnational market settings. ${ }^{17}$ Individual rights protections (in the language of equality and universalism) are being marginalised in favour of neoliberal narcissism, and irredentist securitisation. ${ }^{18}$ It is no longer so much globalisation (or internationalism before it) that threatens secure conceptions of constitutional legality, but the spread of neoliberal exclusionism through the means of globalisation which erodes the human rights connection, if the latter is seen as an essential legitimator of state-centred constitutions. ${ }^{19}$

In the context of globalisation as crisis, or operating across global crises, despite the convention-sourced rights discourse speaking a contrary message,

13 For a telling expression of the role of oppression in modernisation, see P. Freire (2000) The Pedagogy of the Oppressed, New York: Bloomsbury.

14 See M. Findlay (forthcoming) 'Flipping the Other Way: Access Not Protection, and the Role of Rights'. 703-31.

15 S. Mudge (2008) 'What is Neo-liberalism?' Socio-economic Review 6(4),

16 J. Dunning (1997) Alliance Capitalism and Global Business, London and New York: Routledge.

17 A. Bali and A. Rana (2018) 'Constitutionalism and the American Imperial Imagination', Uni of Chicago L.R. 85(2), 257-92.

18 M. McCluskey (2003) 'Efficiency and Social Citizenship: Challenging the Neoliberal Attack on the Welfare State', Indiana Law Journal 78(2), 783-876; J. Deukmedjian (2013) 'Making Sense of Neoliberal Securitization in Urban Policing and Surveillance', Canadian Review of Sociology 50(1), 52-73.

19 J. Habermas (2008) 'The Constitutionalization of International Law and the Legitimation Problems of a Constitution for World Society', Constellation 15(4), 444-55. 
it is reasonable for the peoples of the global South in particular to be circumspect about rights in the universalist $\operatorname{sense}^{20}$ as a legitimating language of democratic governance, if instead one considers neoliberal exceptionalism ${ }^{21}$ as ensuring the rights of the rich.

As a process of international engagement, globalisation should provide legitimate legal pathways for wider representation and democratic rights universalism. ${ }^{22}$ But its capture by neoliberal global economic priorities, protectionist at one level and imperially invasive on the other, has meant that globalisation is more an exclusive than an inclusive phenomenon. ${ }^{23}$

Advocates of globalised legality emphasise the proliferation of rule of law and constitutional legality as profound benefits from the translocation of legal traditions. ${ }^{24}$ Others have criticised this ideology for failing to interrogate its neo-colonial fundamentals and the exploitation it obscures. ${ }^{25}$ For the next few sections, this chapter looks at the globalisation of legal institutions, values and economic dominion, to reveal how the problem of discrimination and exploitation is not globalisation, but the messages it is meant to carry or conceal. ${ }^{26}$

\footnotetext{
20 Rights discourse is a minefield of academic contention when it comes to understanding constitutional/democratic legality. For the purposes of this chapter I am narrowing the consideration of rights to the form that is embodied in United Nations doctrine of individual rights universally available to mankind and fundamentally protected by the global community as the essence of human dignity. See J. von Bernstorff (2008) 'The Changing Fortunes of the Universal Declaration of Human Rights: Genesis and Symbolic Dimensions of the Turn to Rights in International Law', European Journal of International Law 19(5), 903-24.

21 S. Thobani (2018) 'Neoliberal Multiculturalism and Western Exceptionalism: The Cultural Politics of the West', Fudan Journal of the Humanities and Social Sciences 11, 161-74.

22 M. Findlay (2017a) 'Masking Neo-liberal Development: Polanyi, Rule of Law and Dis-embedding Dynamics', International Journal of Development Issues 16(3), 230-44.

23 Findlay (2019) 'Regulatory Interface: Polanyi, the Market Social and Legal Agency', https://papers.ssrn.com/sol3/papers.cfm?abstract_id=3372671 (accessed 1 June 2020).

24 W. Twining (2000) Globalization and Legal Theory, London: Butterworths.

25 A. Hammoudi (2013) 'Reconstituting the Hegemony of Western Law in the Third World, A Post-colonial Critique of Twining's General Jurisprudence', Transnational Legal Theory 4(4), 527-48.

26 J-M. Barretto (ed.) (2013) Human Rights from a Third World Perspective: Critique, History and International Law, Newcastle upon Tyne: Cambridge Scholars Publishing.
} 


\section{Neoliberal Globalisation - The New Empire}

Today, globalisation might be viewed as some mystical short-hand for the reach of mega-capitalism, serving to camouflage the organisation of hegemonic power impeding the struggle for equitable social justice. ${ }^{27}$ As the compression of time and the annihilation of space, ${ }^{28}$ the present era of globalisation overcomes spatial/temporal demarcations to complement neoliberal economic imperialism through technology and capital. ${ }^{29}$

The paradoxes of globalisation are many. One culture, many cultures; interdependence and integrity - forces to unity and to recognise difference.

This is all the more immediate in the transitional phase of globalization which defies cultural integration. Having said this our world is still far from the universalized culture in all quarters. Globalization is a transitional state. It is illusory and potentially distracting at this stage of the globalization process only to concentrate on the collapsing of time and space without recognizing the diversity of human consciousness that remains. ${ }^{30}$

\section{Even so,}

Globalisation as a concept refers both to the compression of the world and the intensification of consciousness of the world as a whole ... both concrete global interdependence and consciousness of the global whole. ${ }^{31}$

Despite its fragmentation, predisposition to hegemony, and cultural contradictions, globalisation will not be contained, expanding through some spaces and constricting others. It strangles the bargaining power of labour on the move,

27 In this sense power is conceived across economic terrain and as such, hegemony is not simply manifest through political alliances, but instead joins mega-capitalist economic interests that otherwise might share neoliberal commonalities but differ in polit-


Eat Cake": Globalisation, Postmodern Colonialism, and the Possibilities of Justice', Law and Society Review 31(2), 207-35.

28 D. Harvey (1989) The Conditions of Postmodernity, Oxford: Blackwell, p. 293.

29 R. Martinez (1998) 'Globalisation and the Social Sciences', Social Science Review 35(4), 601-13.

30 A. Giddens (1996) 'Anthony Giddens on Globalisation: Excerpts from a Keynote Address at the UNRISD Conference on Globalisation and Citizenship', UNRISD News (United Nations Research Institute for Social Development Bulletin) 15, 4-5, cited in Findlay (1999), p. 3.

31 R. Robertson (1992) Globalisation: Social Theory and Global Culture, London: Sage, p. 8; cited in Findlay (1999), p. 3. 
while expanding the boundaries of trade even in the face of protectionism. ${ }^{32}$ Recognising these push/pull dynamics is essential when explaining the manner in which globalisation advances liberal democratic political dominion and global free market economic dogmatism, even in a world order repositioning around tribalist nationalism. ${ }^{33}$

It could be said equally that globalisation has hastened the advent of the 'post-human', ${ }^{34}$ through the manner in which it has facilitated dispensing with more universal human rights priorities underpinning liberal social ordering, in preference for selective economic development that places the market and its units of production above the social and human capital as lives that matter. In so doing, social, economic and cultural rights have been excluded from the 'rule of law' push that legitimates a more blatant hegemonic agenda. ${ }^{35}$ The mystifying and dehumanising consequences of the 'rule of law' discourse are so often forgotten in the rush to trade-mark modern constitutional colonialism (particularly in reconstructing states) with 'rule of law' rights promises. Much has been written by constitutional evangelists, and ignored by constitutional consultancies, concerning the dangers inherent in assuming that the rule of law guarantees equality, when in fact it is a requirement for market certainty in the advance of North/South world modernisation. ${ }^{36}$ If the argument is correct that global society has been subsumed under mega-capital such that the inside can no longer be distinguished from the outside, ${ }^{37}$ then the social inequalities that neoliberalism generates and on which it feeds are more deep-set than serial dislocations in market opportunity. In particular, it is largely accepted in free

32 Findlay (2015) Property, Labour and Legal Regulation; Dignity or Dependence?, Cheltenham, UK and Northampton, Mass., USA: Edward Elgar.

33 Politics advocating nationalism is not inconsistent with neoliberal individualism, even if it impugns the collectivist possibilities of globalization. See T. DeMichele (2016) 'Neoliberal Globalization and Nativist Protectionism Explained', http://factmyth.com/neoliberal-globalization-and-protectionism-explained/ (accessed 3 June 2020).

34 C. Wolfe (2009) What is Posthumanism?, Minneapolis: University of Minnesota Press.

35 J. Stromseth, D. Wippman and R. Brooks (2006) Can Might Make Right? Building the Rule of Law after Military Interventions, Cambridge: Cambridge University Press; Findlay (2013); Findlay (2017).

36 M. Thorton (2010) 'Free Trade and Justice: A Discomforting Liaison', in H. Irving, J. Mowbray and K. Walton (eds) Julius Stone: A Study in Influence, Sydney: Federation Press, chap. 11.

37 M. Hardt and A. Negri (2000) Empire, Cambridge, Mass.: Harvard University Press. The suggestion here is that the meta economic frame has so subsumed its essential component parts that the elements of capitalist production cannot be distinguished from the globalised context of multi-national commerce. Labour, as such is not a located human enterprise, but a global transactable to be bought at the cheapest price. 
market thinking that 'freedom' to participate in most exchange markets will be conditional on structural inequalities and consequent stakeholder power dispersal. ${ }^{38}$ Neoliberal economic ordering necessitates power differentials within and across markets to stimulate individualist wealth creation. Examples of this are myriad in the North world reliance on undervalued South world labour markets, markets wherein the domestic social (of labour commodification) is dis-embedded by the external market 'anti-social' pressures coming from North world materialism. ${ }^{39}$

The market/social which indemnifies globalisation as a potential frame for contemporary social bonding has transformed from post-World War II welfare orientations to the mass economic imperialism of Reagan/Thatcher and beyond, the resistance against which is inevitable. ${ }^{40}$ Global neoliberalism, at least prior to the international financial collapse of 2008, constricted rational foundations for any critique of global economic order which otherwise would support social resistance in terms of justice, as nothing more than naïve revisionism. With the market acting as the measure of all things it has been the assumed wisdom for decades that beyond modification, an anti-market social conscience stands opposed to the development/growth mission of globalisation.

Market maximisation in global governance contexts designed to ensure the private property arrangements on which Western market dominance is prefaced, determines and diffuses a version of legality incapable of challenging fundamental market inequalities. ${ }^{41}$ Along with this, rights discourse is dragged from universal aspirations to some 'merit-based' distortion consistent with neoliberal individualism. Constitutional frames promoted through globalisation are servants of neoliberalism when they focus on the infallibility and indefatigability of private property rights.

The orthodox global economic development model works to sideline state regulatory capacity, often through a recognised apprehension of corruption pathways, while close relationships between government, business and the financial sector emerge in preferred environments of ineffective corporate accountability. ${ }^{42}$ In the vulnerable domestic governance environments of the

\footnotetext{
38 M. Findlay and S.W. Lim (2014) Regulatory Worlds: Cultural and Social Perspectives When North Meets South, Cheltenham, UK and Northampton, Mass.: USA: Edward Elgar.

39 Findlay (2015).

40 M. Foucault (1981) The History of Sexuality, Volume One (trans. R. Hurley), London: Penguin, p. 95.

41 Findlay (2015).

42 Findlay (2017), chap. 5. M. Findlay (2018) 'Corruption as Business across Market Contexts', in L. Campbell and N. Lord (eds) Corruption in Commercial Enterprise: Law, Theory and Practice, London: Routledge, chap. 2.
} 
South, opened up to North world development, deceptive crisis/risk evaluation is prevalent, for instance, where the dangers inherent in under-regulated natural resource exploitation are traded off against the risk of foreign capital flight through responsible regulation. ${ }^{43}$ Globalised economic development models not only advance discriminatory hegemonic interests, but also work from the same empire-centred governance preconditions as did their colonial progenitors. In particular, the class-favouring governance climate for transplanted colonial law enables national political/economic elites in post-colonial states to control law in similar fashion to how it was subsumed into colonial administration. As a consequence, corruption for mutualised benefit of the local elites and absentee investors proliferates, advancing discriminatory market advantage and oppressing any fair sharing of GDP, creating a crisis of domestic governance. ${ }^{44}$

Discriminatory developmental frames (e.g. Foreign Direct Investment) align Western investment benefits with the exploitation of local resources, further limiting the capacity of the state and domestic law to advance social good, and assert fairer local social distribution claims. Ultimately, the neoliberal global economic order works from unsustainable market structures straining traditional social bonding, about which international law says little.

Neoliberal globalisation is more than a dominating globalist ideology. It is the application of new communication technologies to advance a market model of strategic pairing: global trade with deregulation and economic imperialism with cultural and political dominion. While globalisation has a mercantile imperative, neoliberalism does not promote integrated market emancipation through some form of inclusive or even representative global transaction of shared benefit. At this level, neoliberal globalisation is a story of what is, and what is not enabled through global spaces. It is not free market, it is not classical liberalism, it is not neo-classical economics nor is it Keynesian. Neoliberal globalisation has clearly blossomed at the expense of traditional liberal social values and universal governance checks and balances that constitutional legality is said to condone.

Along with understanding globalisation as the context for the neoliberal subjugation of universal rights and thereby much of the spirit of constitutional legality, it is also useful specifically to identify neoliberalism as it is viewed in this analysis - neoliberalism, and how it dis-embeds from society. In the context of constitutional legality and its neoliberal objectification of rights,

43 I. Bremmer (2005) 'Managing Risk in an Unstable World', Harvard Business Review https://hbr.org/2005/06/managing-risk-in-an-unstable-world (accessed 3 June 2020).

44 Findlay (2017). 
a more detailed reflection on rule of law discourse as a neoliberal market condition is useful when critically considering the dangers inherent in constitutional universalism within a neoliberal governance frame.

In advancing the interesting connection between globalisation and constitutional transplantation as a stabilising force for neoliberal market expansion, ${ }^{45}$ it is necessary to look more deeply at the 'rule of law'. As is argued in the next section, the neoliberal project for globalisation is assisted through rule of law's market masking functions.

\section{Rule of Law Dystopia}

From a North world trading perspective, rule of law market conditions provide comfort to the speculator in mercantile dealings. In this tradition, it is North world legalism and North world trade advantage which assumes rule of law market conditions.

the dominance of Western legalism is largely taken as a given. As a result, analysts of domestic and international law tend to look primarily at the privileged domains of legal interaction amongst lawyers, judges, business people and entrepreneurs, and to ignore the perspectives of ordinary people whose culturally informed normative understandings of law may be very different. ${ }^{46}$

Like it or not, in the South world, the rule of law is a post-colonial transplant, however it is constrained and utilised. The relationships between legal orientalism, ${ }^{47}$ capitalism and global political economy oblige rule of law expansionism to push aside aspirations for a more cosmopolitan legality. ${ }^{48}$ Rather than empowering the rights-less, legal orientalism (masked as rule of law) confirms the economic marginality of the South world and the centrality of the hegemonic North. ${ }^{49}$ In this exclusionist climate for law, national elites within post-colonial states flourish in hegemonic miniatures favouring the North, and reaping the benefits of socio-economic development models which advance capitalist priorities which may not align with domestic market sustainability.

\footnotetext{
$45 \quad$ Findlay (2017), chap. 5.

46 E. Darian-Smith (2013) Laws and Societies in Global Contexts: Contemporary Approaches, Cambridge: Cambridge University Press, p. 256. Also, B. Rajagopal (2003) International Law from Below: Development, Social Movements and Third World Resistance, Cambridge: Cambridge University Press, p. 402.

47 E. Said (1978) Orientalism, New York: Vintage Books.

48 De Sousa Santos and Rodriguez-Garavito (2005).

49 The reality of trading interdependencies might speak in reverse of this assumption. For example, North world retail expansion if inextricably dependent on the exploitation of undervalued South World labour.
} 
As such, the dis-embedded domestic market operates without rule of law normative imperatives in market practice.

The beauty of the rule of law is its conceptual neutrality. No one - the human rights community, the business community, even the leadership of otherwise totalitarian states - objects to it. ${ }^{50}$

The synergy between rights-based interpretations of the rule of law discourse and equitable global development is said to rest in the competence of legal institutions measured against a liberal democratic governance ideal. This balanced new world order has rarely progressed even from the aspirational if its positive benefits are demonstrated in any equitable market share at a domestic level across the South world. In such evaluations, there is little apparent or ancillary emphasis on evenhanded requirements in substantive private law arrangements.

Central to the rule of law in its expansive understandings is the inextricability of human rights principles such as equality of treatment under the law. These preconditions in commercial trade practice, however, remain subservient to efficient systems indicators such as independent judiciaries, predictable contract outcomes and well-regulated private law market facilitation.

To obtain the benefits of funded development and therefrom to gain participation in the global growth economy, international financial organisations require of South world societies a demonstrated commitment and adherence to rule of law legality. ${ }^{51}$ Consequently, Anglo-American and European legal traditions, and their colonial institutional and administrative vestiges, consolidate prevailing power asymmetries that characterised the colonial separations of North/South worlds, and on which exclusionist private property arrangements are advanced through capitalism..$^{52}$ Legal practices, meanings and imaginations become grounded in externally imposed hegemony, and post-colonial law is long free from contesting indigenous understandings.

It might be said that the international popularity of rule of law legalism rests on its perceived procedural focus rather than more disputed human rights discourses. ${ }^{53}$ This preference becomes particularly apparent when the facilitative

50 Quoted in M. Trebilcock and R. Daniels (2008) Rule of Law Reform and Development: Charting the Fragile Path of Progress, Cheltenham, UK and Northampton, Mass., USA: Edward Elgar, p. 13.

51 P. Ewick and S. Silbey (1998) The Common Place of Law: Stories from Everyday Life, Chicago: Chicago University Press.

52 Findlay (2015).

53 B. Rajagopal (2008) 'Invoking the Rule of Law in Post-Conflict Rebuilding: A Critical Examination', William and Mary Law Review 49, 1345-74, at 1347. 
nexus between rule of law legalism and global development agendas, particularly in terms of facilitating market certainty, is interrogated.

The rule of law is seen as invaluable to international financial institutions as the bedrock of predictable and productive market activity in otherwise uncertain commercial environments. The World Bank presents rule of law as a vehicle for ensuring private rights in contracts and property, which fosters entrepreneurship and investment. ${ }^{54}$ Like the limitations on the human rights realm when rule of law is determined as a market imperative, understanding rule of law narrowly directed to private property rights protections reduces the possibility that social and economic development could have more sustainable and communal dimensions promoting normative commitments that do not have commercial or development applications..$^{55}$

Outside its hegemonic attractions, exporting the rule of law has had limited impact on ensuring accountable and participatory governance. ${ }^{56}$ This failing may be because the rule of law is marketed alongside a model of North world governance in which the state is the centre of functional power, and society is pluralist and engaged. None of these assumptions hold in disaggregated South world state settings. In societies that are alternatively structured through layers of obligation and dependency, centralised state institutional justice retains far less significance than the discipline frameworks of non-state groupings. ${ }^{57}$

The limited commercial focus of rule of law projects in global economic development demonstrate a reluctance by external actors to recognise the complexity of local politics and culture, and to engage meaningfully with their particularities in order to ensure that the rule of law frame can be adapted and take root. For instance, a denial of the existence or value of local legal traditions makes such a disconnect more justifiable from the perspective of rule of law advocates. A consequence of this disengagement is advocating for a 'thin' or minimalist version of rule of law requiring little more than laws for market ordering, and governments' adherence to rules that legitimate political

54 K. Dam (2006) The Law-Growth Nexus: The Rule of Law and Economic Development, New York: Brookings Institution Press. See also T. Carothers (ed.) (2006) Promoting the Rule of Law Abroad: In Search of Knowledge, New York: Carnegie Endowment for International Peace.

55 H. Charlesworth (2010) 'Human Rights and the Rule of Law after Conflict', in P. Cane (ed.) The Hart - Fuller Debate in the Twenty First Century, Oxford: Hart Publishing, chap. 2. See also J. Waldron (2008) 'Legislation and the Rule of Law', Legisprudence 1, 91-123. Pluto Press.

57 Findlay (1999). See also, D. Trubeck and M. Galanter (1974) 'Scholars in Self-Estrangement: Some Reflections on the Crisis in Law and Development Studies in the United States', Wisconsin Law Review 4, 1062-102. 
authority. In this incarnation, the rule of law is unable to endorse and protect economic, social and cultural rights at a local level, above market contingencies and priorities. Because the rule of law now seems apparent through little more than legality and legal institutions, it has lost what Krygier calls its 'telos', the restraint on abuse of power. For this purpose, legal institution and constitution building as development goals may not be enough to ensure the normative benefits enshrined in thick rule of law discourse, when structural inequalities in labour and access to capital comprise the fabric of North to South world trade engagement.

In curbing abuses of power, legal institutions:

always need supporting circumstances, social and political structures and cultural supports, which are not always available and are difficult to engineer. ${ }^{58}$

Missing in this observation are the reasons why cultural supports are absent or withheld, and why attempts at their engineering are often a deluded post-colonial adventure. But where state constitution building is interested in realising the normative possibilities of a thick rule of law, and returning to a rule of law vocabulary better in touch with a rich account of human rights, ${ }^{59}$ it is more likely that legality can be encouraged as the servant of cultural empowerment through political and economic equality. At the same time, Western legal diffusion may be criticised as an agent of hegemonic globalisation. From this position, there can be a more meaningful transposition of legal regulation to protect rather than imperilling South world emancipation. That said, neoliberal economic ordering would attempt to delegitimise any such grounded approach, preferring instead to market a 'masking' rule of law through constitution building that aligns with hyper-individualist growth scenarios.

Rule of law offers two prospects for globalisation captured by neoliberal market models, and one disappointment in those terms. Rule of law could be seen as a mono-cultural project which is consistent with neo-colonial imperialism. In addition, rule of law universalism is compatible with the transplanting and imposition of commercial and trading arrangements developed in North world traditions and for North world advantage. For instance, the legal fiction of the corporation is a North world creation on which the global web of mega-capitalism depends. Against these neoliberal synergies between rule of law and globalisation, the normative framework which largely legitimates the rule of law runs contrary to neoliberal egoist imperatives.

58 M. Krygier (2008) 'The Rule of Law: Legality, Teleology, Sociology', in G. Palombella and N. Walker (eds) Re-locating the Rule of Law, Oxford: Hart Publishing, chap. 3.

59 Advocated by Charlesworth (2010), p. 60. 
If globalisation is not essentially protected in its human face and associated concerns for rights and dignity are not prioritised above individualist wealth creation when socio-economic development is planned and executed, then neoliberal falsifications about merit-fuelled opportunity for all will create conscious confusions between the market and the social, which the chapter will proceed to discuss.

\section{The Market/Social}

To better understand globalisation's current neoliberal entrapment, it is useful to reflect on the neoliberal determination of the social as inseparable from market maximisation. To help break this connection, a more inclusive reading sees globalised society as a system of communications. ${ }^{60} \mathrm{Law}$, as a moderator of social bonds, is concerned with the structures and mechanisms through which communications develop. Law is the result of a social reality at a particular period of time, and in contemporary contexts its alliance with neoliberal economic priorities is an outcome of the commodification and alienation of private property. ${ }^{61}$ Systems theory presupposes that law should reflect the social perspectives which emerge from specific social sectors (spaces), ${ }^{62}$ and this might explain the present functioning of law within neoliberal market commodification (see Chapter 8).

As neoliberal property arrangements adversely affect expanding disaffected populations through the inequities of a globalised economic empire (see Chapter 2), legal regulation (and rule of law rights discourse) is progressively being blitzed by mundane resistance against neoliberal market exclusionism, such as presently seen with the access revolution resisting intellectual property exclusionism. ${ }^{63}$ Retaliating against this mass movement, constitutional protections of individualist rights to property - emblems of capitalist governance - are out of touch with the new interpretations of property, which Internet empowerment has made possible. ${ }^{64}$

60 D. Schwanitz (1996) 'Systems Theory and the Difference between Communication and Consciousness: An Introduction to a Problem and Its Context', Modern Language Notes 111(3), 488-505.

${ }^{61}$ J. Dellheim and F. Wolf (eds) (2016) Rosa Luxemburg: A Permanent Challenge for Political Economy: On the History and the Present of Luxemburg's 'Accumulation of Capital', Luxemburg International Studies in Political Economy, Basingstoke: Palgrave Macmillan, p. 101.

62 G. Teubner (2007) 'The Private/Public Dichotomy: After the Critique?', Re-public: Re-imagining Democracy https://www.republic.gr/en/ (accessed 4 June 2020).

63 Findlay (2017), chap. 3.

64 Findlay (2017), chap. 2. 
Durkheim's role for law in setting the limits of the conscience collective has taken form through constitutional instruments. The power of constitutional legality to contain neoliberal forces against a more active universalist rights conscience, working within and without the market/social, will be dependent on the nature and strength of social bonds which neoliberalism assails. ${ }^{65}$ There is nothing to say what constitutional instruments, or what they claim to guarantee, can rely on for their legitimacy and potency on the normatively closed system of law, if the bonds that make law a social fact have been weakened and strained by individualist self-interest. For instance, the commodification of property and associated rights to benefit and to access are becoming less and less determined and moderated by law in market economies. Even so, law as a dis-embedding agent in the exercise of property arrangements in the neoliberal market/social is ineffectively mounting a counter-movement against mundane resistance ${ }^{66}$ which in turn has lost faith in the relevance of universalist rights and constitutional guarantees.

One of the large red flags for anyone advocating the exporting of constitutionality through the globalisation of legal traditions, is evidence of the neoliberal rallying cry that the enjoyment of private property is a fundamental human right. Many constitutions enshrine this thinking. Both public and private law in North world traditions take up such thinking. In this way, legal mechanisms like contracting are performing a central role in the reactionary but certain development of the neoliberal counter-movement that depends on property rights and obligations.

The current era of globalisation has radically re-ordered how societies interconnect, and the role which law plays in the process of social bonding. A critical analysis of property and law operating in the market and social contexts of globalisation, evincing a particular interest in the intersection between law and society in states of change, cannot ignore the impact of new communication technologies on actual and digital communities. The Internet information revolution, for instance, has radically facilitated the economic and political reach of globalisation and left the conventional relationships propagated and maintained by the law/property nexus (such as patents and copyright) in the dust of change. What this revolution in access to and valuing of property means for the regulatory future of law depends on how law and property continue to transform in socially located arrangements, rather than market-confined constraints.

65 M. Granovetter and R. Swedberg (eds) (1992) The Sociology of Economic Life, New York: Westview Press.

${ }_{66}$ Mundane resistance is explored in the context of the information access revolution in Findlay (2017), chap. 3. 
Until recently, capitalism has antipathetically relied on law to facilitate the determination of exclusive property arrangements in market settings where possession comes at a price. It could be argued that private law in particular was co-opted within the capitalist economic mode, such that law became a marketable commodity and thereby advanced the interests of the capitalist client, through ensuring the exclusivity of property transactions. ${ }^{67} \mathrm{~A}$ dominant capitalist world economic order, neoliberal in its present enunciation, depends on traditional property arrangements offering economic power courtesy of exclusive access to what the law designates as property rights, and enormous opportunities for wealth creation via the exclusive transaction of possession. However, through similar market conditions which are now stimulating a dispersal of power to previously weakened market stakeholders, the ability to generate wealth and power is no longer solely situated in limited private property rights and relationships, but as a consequence of information and its reach.

The creation of information, its mining and access can generate wealth and power, independent of one's social or economic location. More importantly, Internet information and knowledge exist in a spatial and temporal stratosphere that conventional state-based and international legal enforcement frames are now largely powerless to grasp, contain and regulate. In the case of workforces and trade we are also witnessing, through conditions such as unsustainable socio-demographics in the general population, and the rise of grass-roots resistance among the comfortable as well as the marginalised, ${ }^{68}$ novel market conditions for revaluing essential commodities such as labour and land beyond the money price they can command.

The market/social, Polanyi would argue, is wracked by dis-embedding forces that trade fictitious commodities in order to advance increasingly unsustainable wealth creation. ${ }^{69}$ In this market/social context, it is important to question: what is the nature of social relations that law should regulate? ${ }^{70}$ Where

67 I. Balbus (1977) 'Commodity Form and Legal Form: An Essay on the "Relative Autonomy" of the Law', Law and Society Review 11(3), 571-88. I agree that the debate between instrumentalist and formalist interpretations of law has been misleading, based as it is on the false dichotomy between autonomy and the influence of the will of extra-legal actors. Indeed, law has an autonomy which acts as a powerful commodity for influential actors in capitalist property relations by proposing a system of 'rights' around which property can be artificially alienated.

${ }_{68}$ In the present context, this refers to resistance which emanates from individualist or popular and spontaneous opposition, usually without formal structuring or organization.

69 K. Polanyi (2001) The Great Transformation: The Political and Economic Origins of Our Time, Boston: Beacon Press.

${ }_{70}$ R. Cotterrell (2013) 'The Nature of Law in Transnational Economic Networks', in A. Perry-Kessaris (ed.) Socio-legal Approaches to International Economic Law: Text, Context, Subtext, London: Routledge, chap. 10. 
rights are prioritised to protecting the individual's enjoyment of property, it is difficult to see how law steeped in a discourse of universal rights can transform into a market force which constructively subverts ${ }^{71}$ exclusionist traditions and relationships, hiding behind the rights façade.

If globalisation is to be unhooked from its neoliberal economic trajectory, what is essential is law's role in creating safe spaces for interrogating the 'right directions' in which globalisation should be achieving market and social engagement.

\section{Law as a Tool for Globalised Market Space}

Reflecting on the moral dimensions of globalisation, Teubner argued that law should observe and establish contact with social systems as 'communicative centres of reflection' which generate social values and interests. ${ }^{72}$ For social values to infuse and emerge out of legal conversations, economy alone cannot form the only backdrop against which rights (and more fundamental constitutional legalities) are to be determined. Understanding law as a transformational social force and not only a charter of sometimes-distant universal protections, is more than to interrogate values and interests as they are translated and constituted in sub-systems with which law intersects (particularly the market, and market economies), but further to understand law as a communication technique deemed necessary as a limitation to any system. ${ }^{73}$ In this conceptualisation, law should qualify the individualist excesses of neoliberal market exclusionism, rather than facilitate them.

Through such a limitation function, law constrains excess, imbalance and incongruity. In this respect, law recognises the constituting meaning of social realities, ambiguous and conflictual as these may be, and introduces fundamental values inherent to them; values which are more potent than constitutional reassurances largely removed from the daily experience of human indignity which neoliberal economics spawn. In this imagining, law moves from normative concepts to actionable regulation grounded in social realities. Law then has an interventionist social purpose - no longer merely deciding between two colliding individual interests, but also changing the structure of meaning of these conflicts. ${ }^{74}$ An example here would be anti-discrimination

\footnotetext{
${ }^{71}$ E. Ehrlich (2002) Fundamental Principles of the Sociology of Law, New York: Transaction.

72 G. Teubner (1993) Law as an Autopoietic System, Oxford: Blackwell, pp. 86-90.

73 J. Black (1996) 'Constituting Self-Regulation', Modern Law Review 59(1), $24-55$.

74 C. Elizondo (2013) 'Reflective International Economic Law: Balancing
} Economic and Social Goals in the Construction of Law', in A. Perry-Kesssaris (ed.) 
laws in the workplace that seek to achieve equal pay across genders and defeat patriarchal neoliberal employment power hierarchies. From a South world perspective, external protective legality would materialise international conventions with binding force on the North, attacking undervalued sweat-shop labour conditions.

In a practical sense, law has a role in giving meaning to colliding social realities through enabling safe dissent promising dynamic change. ${ }^{75}$ It is a potent social dynamic which can do more than rebalance distorted market bargaining power, although this is profoundly important in a labour context where justice and equality are absent. Too often law has been burdened with the responsibility of removing economic or political injustice, and constitutional legality broadcasts this capacity, at risk of concealing law's collaboration in neoliberal inequity. ${ }^{76}$ This obligation has meant deciding between divergent external realities communicated from society, but usually with market interests dominant, such as debates concerning basic minimum wages. Another example, is the pot-holed pathway to reconciling market pricing policies and human rights access protections in intellectual property disputes $?^{77}$ The issue of state-initiated market regulation over the prices charged by any successful COVID-19 vaccine sponsors and the waiving of patents will test law's regulatory muscle against global pharmaceutical interests, when pressing social benefit needs to be maximised and widespread.

While needing to be sensitive to specific social claims emanating from exclusive market/social spaces (such as intellectual property protection and property rights violation), law needs, on the way to just outcomes, to create institutions and mechanisms for the acquisition of information on which to make balanced regulatory interventions (see Chapter 8). From a position of market/social knowledge, law's capacity for stimulating power dispersal can reconstruct the value of information and therefrom invite informed legal regulation to revalidate itself. Where, for example, a constitutional right to privacy is more honoured in the breach, law needs to recognise the value individuals place on certain messages and their integrity; to moderate expectations when rights discourse is transacted against communal valuing of information economies. It is important to remember that law so relatively informed is not simply capitulating to the neoliberal commodification of data integrity. Instead, it is

Socio-legal Approaches to International Economic Law: Text, Context, Subtext, London: Routledge, chap. 8.

75 A. Jones (2017) 'Due Process of Law' and the Divine Right of Dissent, London: Forgotten Books.

76 Findlay (2017a).

77 W. Grosheide (ed.) (2010) Intellectual Property and Human Rights: A Paradox, Cheltenham, UK and Northampton, Mass., USA: Edward Elgar. 
giving a more nuanced and realistic interpretation of market/social valuing of the property in personal information, and thereby pragmatically mediating contested rights that constitutional language alone cannot distil, particularly when messages are dispersed in digital societies. Federalist approaches by the European Union, for instance, in qualifying market interests in personal data through shifting rights from the licence holder to the accessor alone are unable to modernise constitutional rights to privacy in markets for messages which treat message integrity as negotiable. Personal data protection law designed to create and maintain rights for the data subject that resemble property interests may end up being lip-served as privacy protections in situations of message transaction. ${ }^{78}$ In this vein, a more pressing and all-encompassing issue for legal regulation is to intervene in the nature and scope of how big data is disrupting constitutional rights discourse once framed in terms of individualist litigious remedies. ${ }^{79}$ There is ample evidence in the European Union courts in particular the actions by individuals against tech giants designed to protect personal data integrity (such as the 'right' to be forgotten) are a tortuous, problematic and costly approach to the exercise of personal integrity over commercialised datafication.

Teubner suggested that law is capable of transforming a more dis-embedded market/social in evolving the means of irritation, re-entry and reconstruction processes. Irritation is necessary, so the analysis goes, to initiate the transformation of law. Irritation is usually produced through conflict which can arise out of shifts in the collective conscience.$^{80}$ In this respect, essentially communitarian social conflict presents for law an opportunity to incorporate and subsume external constituencies otherwise outside legal argumentation. When a legal/social construct such as intellectual property has irritated the legal system (claiming rights over disputed notions of property), accompanied by a strong counter consciousness demanding alternative meanings about access to information and knowledge, and their valuing (based on social rather than economic priorities), then law may be forced into a new phase of recognition (or alternatively it might regress into reactionary or partisan determinations). In this way, law is (or is not) an active change agent in the market/social when the normative proscriptions of constitutional legality (like equality,

78 Findlay (forthcoming) 'Flipping the Other Way: Access, Not Protection, and the Role of Rights'.

79 C. Wolf (2013) 'Google and Facebook: Too Big to Sue?', Colorado Biz https:// www.cobizmag.com/articles/google-and-facebook-too-big-to-sue (accessed 4 June 2020).

${ }^{80}$ A concept developed by Durkheim to embody the way in which communal morality is bonded and evolves, with law acting as its porous boundary. 
non-discrimination and fraternity) are relegated to a gloss on the discriminatory excesses of neoliberal market exclusion. ${ }^{81}$

Stepping back to how law is irritated into reconstruction, particularly in the context of static constitutional embedding, it is useful to consider the ways that sub-systems, which can provide the need for law to re-enter a social context with a reconstructed form, possess a constitutive function, because they construct themselves according to their own internal rationality. In a market setting this may mean state intervention through commodity pricing, or even political power to differentiate market preferencing via the application of compulsory licences. In altering the collective consciousness concerning market power and property valuing, sub-systems such as economy and politics have limitative functions over law and vice versa because they establish their own boundaries and thereby cognitively inhibit neighbouring sub-systems. As such, neoliberal economic prioritisation demands small state governance (and therein a reduced capacity for nation state governance to assert constitutional legality in protecting from the nativism of neoliberal exclusion). Against a broad rights-protective function for law, neoliberal economics requires its regulatory imperative only to protect private property 'rights' individually claimed and exclusively actioned. This telescoping of law's transformative scope and capacity has been promoted by globalisation agendas that are, as discussed above and in the chapter to follow, imperial and anything but transformative.

The normative closure of law means that it is only capable of reconstructing the social value and interests of other sub-systems through offering different meanings to their operations according to legal rationality. Constitutional legality is a framework both of closure, and for reconstruction if and when the conditions of governance sub-systems (such as markets) are compatible with its discourse and respectful of its enforcement functions. When the collective conscience transits away from closed constitutional legality, then the effectiveness of constitutions and governance change agents is minimised at points of re-entry and of reconstruction. In this process, law can offer new meaning to globalisation by focusing on its moral dimensions and moving away from seeing globalised systems (economic, social, governance, environmental) as only interpreted in market terms.

In any case, legal rationality, and the underpinnings on which it is based, are not set in stone. Altering and growing the structure of that rationality makes possible the changing of meaning for the operation of other sub-systems and even leading to the breaking down of entrenched divisions, system-to-system.

81 B. Golder and D. McLoughlin (eds) (2017) The Politics of Legality in a Neoliberal Age, London: Routledge. 
An example would be where law moves from prioritising the identification and protection of commodified interests in data, within a private property rationality, to concerns for use and access, within a 'social good' rationality. In addition, law can re-interpret globalisation as an inclusionary social, rather than an exclusionary economic force by determining priorities for its motivation that are not singularly market dependent. The pecking order of sub-systems in their relations with law may in fact diminish law's reconstructive influence through the advancement of power hierarchies that force law into inferior spaces in the market social. This is the outcome when law's value is commercialised, and it cannot break free from a market form. At the same time, law can re-assert its transformative capacity through latching onto compatible normative principles in other sub-systems that do not have a constraining neoliberal market sponsorship.

Universalist and inclusive constitutional legality - not strangled by capitalist commitments to the sanctity of individualised property rights - facilitates market positioning and opportunities for participation based on more than just configurations of power. Legal regulation to declare and enforce universal rather than exclusive rights should be a driver and not a distinguisher of market freedom. As a driver, constitutional legality has the advantage of a closed and compelling normative composition. That normative composition is returned to its purpose in promoting fluid social good, and acting as a community resource thereby, if law and legal agency are untethered from the neoliberal noose. ${ }^{82}$

While irritated (and then irritating) law is reconstructed from conventional legal technologies, it runs in parallel with other frames of social control (such as market competition), permitting critical reflection on the normative masking functions of other frames. In its points of re-entry, transformed law (broken free from neoliberal service) can expose the old spaces which law had occupied - namely, advancing exclusionist wealth creation interests and the dysfunctional applications of normative codes (like unbalanced meritocracy) in otherwise discriminatory market economies.

Irritated law impacts on other legal sub-systems such as the market and its property arrangements, which operate within challenged paradigms such as property rights, and treasure and extol mechanical rather than organic concepts of access, possession and ownership. Property as a neoliberal right is inextricably dependent on exclusionist and mechanical ownership externalities (such as inheritance). In these socially inequitable contexts, this right only has a transitory reality for the few that can use law to enforce its exclusivity.

82 A. Perry-Kessaris and T. Xu (eds) (2013) 'Special Issue: Legal Appropriation: Taking of and by Law', Northern Ireland Legal Quarterly 64(3); Findlay (2017), chap. 7. 
The dynamic of irritated/irritating law is a story of facilitative wrongs (such as unfair contracting terms struck as a result of the power imbalance of the parties), rather than of illusory and masking expressive rights. ${ }^{83}$

Pre-existing legal frames have employed the influence of similar normative constitutions as that of irritated law to defeat social good, where exclusionist wealth creation modifies market access equities. Law in such settings is an irritant, favouring opportunities within other social realities (such as markets for property as knowledge in the information economy) to diminish the core values of normative constitutional rights. Instead, the law perpetuates exclusion in the name of unbridled libertarian enjoyment of private property, and to dis-embed from society in the qualified language of conscionability. Irritation, therefore, will not always better confirm some direction for law which is protective of universalist rights or compatible with constitutional legality. In what contexts of the market/social, therefore, can more equitable legal influences form and flourish? How will globalisation propagate more equitable communication, engagement and sharing assisted by transformed legal motivations for access to property above its narrow commodification?

\section{Irritation, Re-entry and Reconstruction - Can Constitutional Legality Have a Place?}

Social conflicts, mundane or aggressive, from which irritation may arise give law the possibility to reconcile external constituencies outside legal argumentation, such as the imperatives for globalised social engagement. From the vantage point of law as a change agent, it is not sufficient to rely alone on the instruments and discourse of constitutional legality, when these are normatively embalmed but practically decayed when contrasted against social conflicts, and as such deny potentials for re-entry into the social and the reconstruction of a collective conscience torn by neoliberal exceptionalism. Constitutional rights relying on a neoliberal legal infrastructure cannot eventually act against the interests of law's role as a commodity in the market. ${ }^{84}$

That said, constitutional legality as a re-constitutive communication pathway within the market/social might under the right conditions present a capacity for offering binaries such as legal/illegal and breaking these down due to its mechanism of transacting their meaning and thereby determining their legitimacy. Legal in the market context must be more than just tolerated as legitimate and illegal takes on a determination which is not dependent on

83 For a development of the 'rights/wrongs' counter-narrative, see Findlay (forthcoming) 'Flipping the Other Way: Access, Not Protection, and the Role of Rights'.

84 Findlay (2017), chap. 6. 
power. In the sub-system of a market, constitutional legality will only tackle the discriminative consequences of neoliberalism by advancing opposing market permissions, such as fairness and good faith in contracting. If law and legal agency remain almost solely mechanisms for commodifying property value in terms of exclusionist market pricing, thereby discriminating market power and magnifying individualist wealth creation through creating and maintaining property arrangements which depend on enforcement rather than trust and consensus, then the universalist and inclusive message of representative constitutional legality is confounded.

The re-entering context for constitutional legality, as this analysis views it to be, is not through some mechanical transposition of a foreign legal instrument, explained through the abstractions of the rule of law. Rather, what is more likely to produce transformative social benefit would be the employment of an external normative superstructure, to irritate the discriminatory and exclusionist collaborations of legal agency and neoliberal market forces. ${ }^{85}$ Viewing the role of constitutional legality to irritate from without, the market/social may offend those who see constitutional legality as indigenous and evolutionary. It is not necessary to exhaust this argument here, or even discuss whether the two views are helpfully counter-poised. For the sake of argument, limiting the notion of constitutional legality to institutions, forms and discourses crucially connected to the universal rights traditions is sufficient to speculate on its role as an external irritant to the neoliberal capture of globalisation. The critique of a static analysis of constitutional legality centres on the failure of universal rights within the market/social to resist the onslaught of neoliberalism. Beyond walking away from constitutional legality as a change agent for irritation, re-entry and reconstruction within the era of neoliberal globalisation, positioning it as an external irritant against the neoliberal denials of universalism, offers various possibilities to expose and critically reflect on socially positive transformations, not muddied by a compromised rights discourse.

In order to achieve its transformative potential, law operating through the external influences of constitutional legality needs to stabilise the independent expectations of other sub-systems and their participants, by reconstructing them within the context of an inclusive legal rationality. Neoliberalism in its current market iterations is now set against social inclusion and universal rights recognition. Reconstructed law can only enter other sub-systems such as the market and assist in changing the structure of meaning of vital constituents and arrangements, if entrenched divisions between the included and the excluded are also open for irritation and reconstruction. Globalisation as

\footnotetext{
85 Findlay (2017), chap. 7.
} 
a process for extensive social engagement becomes an important platform for this attack on neoliberal exclusion.

Once irritated and reconstructed, re-entry is a key phase through which law can 'internalise the dynamic rationalities developed in other sub-systems and thereby transcend its own conventional boundaries by employing external cognitive forces to ensure its congruence with changing collective consciences' ${ }^{86}$ On the other hand, free of externally imposed limitations (such as exclusionist private property rights) which are inconsistent with powerful contesting collective consciences, law can establish clear processes by which selection, variation and retention of values and interests are made. Only when the interrelation of law is with other sub-systems advocating an inclusive agenda, will the co-evolution of sub-systems such as the economic and the social recreate a more balanced and equitable image of the economy and the social, and vice versa. Constitutional legality expressing universalism, as a change agent, is essentially inclusive and thereby opposed to and opposed by neoliberal market mechanics. It also provides a counter-narrative for the activation of globalisation beyond economic imperialism.

To facilitate the re-entry of the market back into the social, and to enable globalisation to participate in a market frame which is released from neoliberal exclusionism, law invokes a normative framework susceptible to free points of access. By so doing, it communicates to other social realities in ways which both assist in their reconstitution and offers limitations over that process in terms of strong normative constitutional form. Based on a firm commitment to knowledge sharing, the normative frame provides boundaries to the collective conscience on footings such as social-embeddedness, ordering, equality and justice, in the sense of responsible power sharing.

Pashukanis' critique of law as form can expose constitutional legality's universal rights discourse to the criticism of form over function. In doing so, an important opportunity is offered to question law's irritant capacity, and from there its genuine ability, beyond form, to facilitate re-entry into and the reconstructing of the market/social. Such reconstruction is at the heart of my assertion that law can participate in the rehabilitation of globalisation.

However,

The pessimistic worry is that for all the many flaws of constitutional imagination, if a future order is premised ideologically on ... [some] state's raw power, the space for self-constraint and rule-based limitations will continue to recede ... Trump's ascendance has made plain the nature of what has for decades been the American

86 A. Skordas, 'Is there Justice in International Law?' (2009) in C. Calliess, A. Fischer-Lescano, D. Wielsch and P. Zumbansen (eds) Soziologische Jurisprudenz: Festschrift fur Gunther Teubner, Berlin: De Gruyter, pp. 179-200. 
orientation to the world, an orientation guided by neo-liberal commitments, national security presumptions, and unilateral coercion. The silver lining may be that ... other powers or global civil society movements, acting singly or in concert, may yet embrace the aspirational potential of a new international order. Although such an order may not speak the language of American constitutionalism, it also might not be weighed down by US geostrategic constraints and coercive imperatives ${ }^{87}$

If these susceptibilities expressed for the once-undisputed paragon of rights-based constitutional legality are revealed in an age of political populism, how much more might we fear for the resilience of constitutional legality to protect good governance in newly democratising Asian states, searching for the right constitutional mix of Western normative values, and localised social and cultural realities? This challenge is more than a matter of balance or even somewhat oblique mimicry. If constitutional legality is to offer a platform for good governance in such political contexts, through irritating neoliberal sponsorship of law in the market, this chapter argues for a rejection of incipient neoliberal translations of constitutional rights discourse, along with a more robust recognition of the localisation, indemnification and radicalisation of constitutional frames.

\section{GLOBAL MORAL CULTURE}

To this point, there is a significant omission in the argument that law through irritation, re-entry and reconstruction can play an important transformative role in rehabilitating globalisation. For this to happen, there needs to be some normative link subsystem-to-subsystem, so that cognitive recognition can activate change. Inglis reminds us that Durkheim had much to infer about the globalisation process and the globalised world condition. The parallels drawn are a major corrective to radical critiques which reduce globalisation to some bi-product of capitalism and imperialism:

With the increasing interpenetration of hitherto distinct groups at the level of intertwining social relations (and here the argument has resonances with similar themes in the Division du travail), what Durkheim calls the 'international gods' (dieux internationaux) are born. [Explaining how indigenous sub-systems move from a domestic to a 'global' notion of deity.] This is understood as happening through two particular mechanisms. First, at the wholly ideal level, each group's idea of a god fuses with the ideas of the other groups they are in systematic and interpenetrating contact with, and the resulting international god is made manifest as an idea in the minds of all participants. In a way, then, the international gods are the results of a hybridization of different, distinctive mythologies, which start to

87 Bali and Rana (2018), at 292. 
'mingle, combine and borrow from one another', leading to further cross-pollination of the original traditions of belief of particular groups.

Second, at the level of action and in terms of a cult, he sees the international gods as being above all gods of initiation ceremonies. As such, they were generated in, and are celebrated at, the initiation rituals held at 'intertribal assemblies'. Thus 'sacred beings were formed that were not attached to any geographically fixed society'. Their geography is instead much wider, and in effect an international or inter-societal mental habitat without clear borders, a culture spreading over an area without definite limits. Accordingly, the mythological personalities that correspond with this have the same character; their sphere of influence is not pinned down; they soar beyond the particular tribes and beyond space. They are the great international gods. $^{88}$

In this exhilarating interpretation of 'god formation', Inglis offers Durkheim's anthropology to suggest a powerful method of shared and inclusive morality, not incompatible with the reaches of natural law. What is so exciting in this interpretation is the enjoyment of globalised engagement free from economic imperatives, and neoliberal parochiality. Such engagement shares essential and dominant social values. As a framework for social engagement and market re-embedding, globalisation no longer has to operate as a neoliberal economic stooge, promoting individualist wealth creation and denying engagement beyond markets, which is its social essence. Globalisation can create conduits for the sharing of fundamental moral commitments to humanity and dignity that money cannot buy. Therein lies the rehabilitation of globalisation. 